\title{
How to spot a real value proposition
}

\author{
Victor Camlek \\ VP Market Intelligence, Thomson Reuters, Philadelphia, PA, USA \\ E-mail:victor.camlek@thomsonreuters.com
}

It has become fairly common to hear the term "value proposition". It is often featured as a component of a sales and marketing strategy in various ways, such as: advertisements, white papers, case studies or within sales collateral. In fact, the term has become quite familiar, yet when a series of value propositions are evaluated it becomes clear that not all value props are created equally. In fact, many of them appear to be mere statements of features and functions rather than fully developed value statements. Although there are no authoritative bodies that regulate or require the use of value propositions, there has been a sequence of development over the past thirty years that have led to guidelines for the development of a value proposition. This paper will review how to spot a well developed value proposition as well as to determine when a value proposition falls short of the best practice.

What is Value?

"Beauty is in the eye of the beholder". This popular concept is especially true discussing value. The term value has many definitions, however, a definition that includes the following concepts begins the process of understanding what illustrating value is all about. Therefore, the following definition is an important first step in understanding what a value proposition is. Value is defined as:

Worth in usefulness or importance to the possessor; utility or merit: the value of an education. ${ }^{1}$

In business it is very important to be able to demonstrate the value of a product, service or a solution. Achieving this goal requires a methodology, which is known as a "value proposition". Essentially, a value proposition will state the measurable value or tangible customer benefits that a product or service will provide to its customers and will illustrate the return on the investment or other tangible positive outcomes of choosing a particular service provider over its competitors.

The major aspect of this capability that is important to focus on is the notion of "illustrating a return on the investment". This capability to spell out the value of a product or service within the business context of the user is the elusive gold at the end of the trail where so many efforts simply fall short.

Interestingly, the literature associated with value propositions is relatively recent, pretty much evolving over the past thirty years. Prior to this period value was often demonstrated via advertising that utilized a series of claims and capabilities. However, the actual studies devoted to methodologies and impact started to appear during the 1980s as part of a series of notable business books by authors such as Theodore Leavitt and Michael Porter. In addition, a then McKinsey consultant named Michael Lanning added to the knowledge stream when he advocated the notion of "Value delivery systems" [1]. Later on,

\footnotetext{
${ }^{1}$ http://www.yourdictionary.com/value.
} 
Michael Treacy and Fred Wiersema published a seminal article devoted to the way "Value disciplines" are practiced in successful companies [2]. Meanwhile Lanning went on to an independent career setting up a consulting firm devoted to helping clients achieve business value.

The result of these contributions was that certain methodologies became available for strategic marketers to utilize as part of their attempt to engage customers in the context of value rather than intense debates that were basically price negotiations. In addition, the concept of value propositions gained further acceptance when it became part of the Balanced Scorecard Collaborative.

Over the recent past there have been many consultants who have been engaged by companies to provide training in the art of the value proposition. Many have developed their own programs, however, when you look at the various approaches it becomes clear that much of the discipline seems to be derived from the works of Lanning or Treacy. In summary Lanning has emphasized a model that is based on "Delivering profitable value", whereby he describes an enterprise as a "value delivery system that must convey the experience and benefits of their products to customers" [1]. Meanwhile, Treacy and Wiersema illustrated a discipline, very similar to the Michael Porter concepts about strategy, that noted successful businesses demonstrated one of three value approaches. They excelled at either: operational excellence, customer intimacy or product leadership [2].

The three approaches described by Treacy and Wiersema were comprised of three very different approaches which meant that most companies could elect only one mode of operation. For example, operational excellence was based on cost leadership (similar to the Porter strategy). These companies tended to be price leaders who produced low cost solutions. The customer intimacy focused firms, similar to the Porter Differentiation strategy produced superior products and services where from the customer perspective, price was not the issue. The third strategy aimed at product leadership requiring companies to be very innovative and fast moving in terms of development and time-to-market. Regardless, the purpose here is not to dwell on this work, but rather to point out that a successful value proposition must take into consideration the mode of operation that the target company practices. To deliver value to a product leader requires a very different approach and messaging then it would take to describe value to a cost-focused enterprise.

Returning to the Lanning principles, the concept has consistently been that to demonstrate value the seller must have a thorough understanding of the target customer and then to develop a fact-based argument that spells out the business value and trade-offs based on intimate knowledge of the customer situation.

The point of all this is that value propositions are not simply related to product features, functions or the familiar "bells and whistles". A customer should not be expected to purchase a product because the vendor says it is better than all the other options. Rather the vendor should illustrate from the perspective of the customers' eye what the actual capability that is offered adds to the customers business. Preferably, this value is presented in terms of adding new revenues, improving the customer relationship or improving operational efficiencies. The ability to literally spell this out, within the customer jargon and competitive environment results in a measurable statement of value, rather than a simple boast or claim.

The value proposition literature further spells out various situations whereby a product development practice may believe they are following principles to develop value-based solutions as we're describing yet still fall short of hitting the mark. One example of this is known as a "customer compelled" approach whereby the vendor becomes a puppet or a mime, simply developing and stating what they believe the customer wants to hear rather than risking an independent approach that results in a better product based on a true assessment of the customer's value equation. 
Another trap is the "internally driven" approach whereby companies may produce excellent products and value, but tend to stay within an established comfort zone based on proven experience. Obviously, this approach has its limits, especially when conditions change and technology disrupts the nature of a market. In this case a company could easily become a victim of its own success and be caught off-guard when conditions change.

A third quasi-approach is simply to imitate the perceived best solutions and aim to match what the competitors offer.

Therefore, the best approach is to develop a market-centric value strategy, whereby the value proposition is developed following a thorough examination of the customer situation. This may be achieved by a combination of research techniques including primary market research including actual observations (ethnographic research) of the customer's daily workflow.

To understand what value actually means it is helpful to look at a series of concepts that may then be translated into examples. Chart 1 helps illustrate the concept of value as it increases along the journey up the value-chain growing from a basic function (utility) to a true customer value.

The move from basic utility to a solution that adds customer benefits that may be translated into actual value statements should be the desired outcome of value-driven product development. Chart 2 translates the concepts to actual generic products and provides some examples of how familiar products may be positioned along the value-chain.

A very important concept that is vital to the successful value proposition is the language employed to deliver the message. Experts believe that the best approach is to use simple and easy to understand statements based on the jargon practiced within the customer's home market or industry. Overly complex equations and detailed technical explanations may lead to an over-kill that destroys the essence of the message that must be delivered.

\begin{tabular}{|c|c|c|c|c|c|}
\hline & $\begin{array}{l}\text { Basic Product } \\
\text { or Utility }\end{array}$ & & $\begin{array}{l}\text { Customer } \\
\text { Basic } \\
\text { Needs }\end{array}$ & $\begin{array}{l}\text { Customer } \\
\text { Benefits }\end{array}$ & $\begin{array}{l}\text { Customer } \\
\text { Value }\end{array}$ \\
\hline Consumer & $\begin{array}{l}\text { - Basic utility } \\
\text { - Useful in a } \\
\text { particular way }\end{array}$ & $\begin{array}{l}\text { Define what the } \\
\text { product does } \\
\text { - Show a range } \\
\text { of capabilities }\end{array}$ & $\begin{array}{l}\text { - To fulfill a basic } \\
\text { purpose } \\
\text { - Reliability } \\
\text { - Reasonable } \\
\text { price }\end{array}$ & $\begin{array}{l}\text { - Adds } \\
\text { capabilities } \\
\text { beyond simple } \\
\text { utility } \\
\text { - Offers an } \\
\text { enhanced } \\
\text { experience }\end{array}$ & $\begin{array}{l}\text { - A capability } \\
\text { that outweighs } \\
\text { the price } \\
\text { - A visible result } \\
\text { of using the } \\
\text { product }\end{array}$ \\
\hline Business & $\begin{array}{l}\text { - Provides a } \\
\text { basic business } \\
\text { capability } \\
\text { - Fulfills a } \\
\text { business } \\
\text { requirement }\end{array}$ & $\begin{array}{l}\text { - Serves a } \\
\text { business } \\
\text { requirement } \\
\text { - Adds a range } \\
\text { of simple to } \\
\text { complex } \\
\text { capabilities }\end{array}$ & $\begin{array}{l}\text { - A basic } \\
\text { component of } \\
\text { some business } \\
\text { function } \\
\text { - Fulfill some } \\
\text { work purpose }\end{array}$ & $\begin{array}{l}\text { - A tangible } \\
\text { reward that the } \\
\text { product offers } \\
\text { - A capability not } \\
\text { simply } \\
\text { available from } \\
\text { competitors }\end{array}$ & $\begin{array}{l}\text { A measureable } \\
\text { return on the } \\
\text { customer } \\
\text { investment that } \\
\text { creates a } \\
\text { competitive } \\
\text { advantage }\end{array}$ \\
\hline
\end{tabular}

Chart 1. Understanding value from utility to advantage. (Colors are visible in the online version of the article; http://dx.doi.org/ 10.3233/ISU-2010-0615.) 


\begin{tabular}{|c|c|c|c|c|c|}
\hline & $\begin{array}{l}\text { Basic Product } \\
\text { or Utility }\end{array}$ & $\begin{array}{l}\text { Product } \\
\text { Features }\end{array}$ & $\begin{array}{l}\text { Customer } \\
\text { Basic } \\
\text { Needs }\end{array}$ & $\begin{array}{l}\text { Customer } \\
\text { Benefits }\end{array}$ & $\begin{array}{l}\text { Customer } \\
\text { Value }\end{array}$ \\
\hline $\begin{array}{l}\text { A light } \\
\text { bulb }\end{array}$ & $\begin{array}{l}\text { - Lights your } \\
\text { room }\end{array}$ & $\begin{array}{l}\text { - Light is based } \\
\text { on \# of watts } \\
\text { - Some bulbs } \\
\text { last longer than } \\
\text { others }\end{array}$ & $\begin{array}{l}\text { - Adequate } \\
\text { light for task } \\
\text { at hand }\end{array}$ & $\begin{array}{l}\text { - Light } \\
\text { whenever } \\
\text { needed }\end{array}$ & $\begin{array}{l}\text { - Longer lasting } \\
\text { bulbs can be } \\
\text { quantified in } \\
\text { terms of cost } \\
\text { savings }\end{array}$ \\
\hline A car & $\begin{array}{l}\text { - Transportation } \\
\text { from Point A to } \\
\text { Point B }\end{array}$ & $\begin{array}{l}\text { - Standard } \\
\text { driving } \\
\text { Enhanced } \\
\text { MPG, style, } \\
\text { handling, etc. }\end{array}$ & $\begin{array}{l}\text { - To get from } \\
\text { Point A to } \\
\text { Point B }\end{array}$ & $\begin{array}{l}\text { - Ease of } \\
\text { driving, } \\
\text { improved } \\
\text { handling, } \\
\text { image, safety }\end{array}$ & $\begin{array}{l}\text { - Metrics that spell } \\
\text { out savings from } \\
\text { MPG and } \\
\text { anticipated } \\
\text { product reliability }\end{array}$ \\
\hline $\begin{array}{l}\text { Online } \\
\text { database }\end{array}$ & $\begin{array}{l}\text { Online access } \\
\text { to information }\end{array}$ & $\begin{array}{l}\text { Number of } \\
\text { records, } \\
\text { coverage, } \\
\text { specialization, } \\
\text { full text, etc. }\end{array}$ & $\begin{array}{l}\text { - Online access } \\
\text { to information } \\
\text { of specific } \\
\text { coverage }\end{array}$ & $\begin{array}{l}\text { One-stop } \\
\text { access to } \\
\text { numerous } \\
\text { content } \\
\text { sources } \\
\text { - Taxonomy, } \\
\text { indexing, etc. }\end{array}$ & $\begin{array}{l}\text { Measureable } \\
\text { savings from } \\
\text { multiple sources; } \\
\text { improved } \\
\text { efficiency; returns } \\
\text { that measure } \\
\text { improved cust. } \\
\text { satisfaction }\end{array}$ \\
\hline
\end{tabular}

Chart 2. Specific examples based on a value-chain. (Colors are visible in the online version of the article; http://dx.doi.org/ 10.3233/ISU-2010-0615.)

The following checklist is very useful in determining whether a product or value proposition is indeed meeting the mark.

- Is it framed from the customer's perspective, instead of your perspective.

- Is it superior? Would the value proposition, if delivered, surpass alternatives? Would customers agree?

- Can you deliver it? If not, could you build the capabilities needed?

- Does it align with your strategy?

- Is it sustainable? If so, for how long? How fast would competitors react? What about other changes in the business environment?

- Is it profitable to both the customer and to you?

- Does it address the customer's pain points or areas of high interest?

- Is it measurable?

By searching for the major components of this check list whenever encountering a value proposition, the reader will be in a much better position to determine if value is actually being described or a mere series of claims and bragging is on the table. This checklist also works from the perspective of product development whereby the development team can discern whether value is actually being achieved within their development cycle.

\section{Conclusion}

Primary points that spell out the importance of value propositions include:

- The concept of value is a significant juncture aligning management, strategy, marketing and sales. 
- There is no requirement to provide a value proposition. However, a carefully crafted VP could bolster competitive advantage when it is utilized as a strategic marketing tool.

- Customer focus is critical to successful performance. However, simple "listening" may not be enough! Experiencing the actual customer environment and challenges should lead to innovative breakthrough opportunities for both the customer and supplier that are perhaps not on the current radar.

- It is best to position all value statements from the customer perspective in simple and easy to understand language.

Given this knowledge the challenge of the strategic marketer is to craft meaningful value propositions that conform to the methodologies established by the experts we cited. From the customer perspective the challenge is to spot and embrace true value propositions as well as to challenge the less than stellar attempts that rely on bragging about attributes from a unilateral selling perspective rather than demonstrating the problems that may be solved from the perspective of the customer along with some measurable statement of what success looks like in terms of revenues, savings, improved operations or improved customer relationships.

\section{References}

[1] M.J. Lanning, An introduction to the market focused philosophy, framework and methodology called Delivering Profitable Value $^{\odot}\left(\mathrm{DPV}^{\odot}\right)$, available at: http://www.exubrio.com/white-papers/DPVIntro-eXubrio.pdf.

[2] M. Treacy and F. Wiersema, Customer intimacy and other value disciplines, Harvard Business Review 71 (1993), 84-94. 